\title{
Red Blood Cell Transfusion in Preterm Infants: Current Evidence and Controversies
}

\author{
Claire Howarth $^{\mathrm{a}}$ Jayanta Banerjee ${ }^{\mathrm{b}}$ Narendra Aladangady ${ }^{\mathrm{a}}$ \\ ${ }^{a}$ Homerton University Hospital NHS Foundation Trust, London, UK; ${ }^{\mathrm{b}}$ Imperial College Healthcare NHS Trust, \\ London, UK
}

\section{Keywords}

Premature infants · Blood transfusion · Anaemia · Perfusion . Physiological parameters - Necrotizing enterocolitis .

Neurodevelopment · Near-infrared spectroscopy · Placental transfusion

\begin{abstract}
The current evidence regarding the indication, advantages and risks of red blood cell transfusion (RBCT) for preterm infants is discussed. This is an important area in Neonatology to be examined given that $90 \%$ of extremely low birth weight infants receive $\mathrm{RBCT}$ and many controversies remain regarding when to transfuse and the risks of RBCT. The various treatment thresholds and guidelines used are presented and we compare the short-term clinical benefits of liberal and restrictive RBCT in preterm infants; the majority of these are equivocal and sadly long-term outcome data is limited. The latest evidence on how anaemia and blood transfusion affect organ perfusion in preterm infants is presented. This is important when trying to establish the optimal trigger threshold for RBCT in preterm infants, especially because the knowledge about the adaptive physiological responses to anaemia in very low birth weight infants and the effects of RBCT at various levels of anaemia is also inadequate. Further research into the physiological adaptive response to
\end{abstract}

anaemia of varying degrees and to RBCT at different levels of anaemia in preterm infants of different gestational and post-natal ages is needed before we can conclusively guide the optimal timing and trigger thresholds for RBCT in preterm infants.

(c) 2018 S. Karger AG, Basel

\section{Introduction}

Considerable advances in Neonatology over the last 2 decades have resulted in an increased survival of preterm infants [1] and consequently the incidence of transfusions has increased exponentially [2], especially in very immature infants (23-25 weeks of gestation) [3]. Overall since the 1990s to date it has been reported that up to $90 \%$ of extremely low birth weight (ELBW) infants and $58 \%$ of preterm infants $<32$ weeks of gestational age receive red blood cell transfusions (RBCT) [2-4], mainly due to iatrogenic phlebotomy losses and ventilatory requirements.

In general, RBCT is beneficial to the sick preterm infant undergoing intensive care [5] by increasing circulatory haemoglobin $(\mathrm{Hb})$, improving tissue oxygenation, and reducing the cardiac output to maintain the same level of oxygenation [6]. 
However, little is known regarding the effects of RBCT at various levels of anaemia on the delivery and utilization of oxygen [6]. There remain the generic risks of RBCT (e.g., transfusion of incorrect blood due to errors, or transfusion-related reactions), but in the neonatal population there is increasing concern regarding associations with intra-ventricular haemorrhage (IVH), bronchopulmonary dysplasia (BPD), retinopathy of prematurity (ROP), and necrotizing enterocolitis (NEC), all of which cause significant morbidity and mortality in preterm infants $[2,7-10]$.

\section{Current Indications}

Anaemia becomes symptomatic when there is an imbalance between oxygen delivery and consumption [11] which may not occur universally at the same $\mathrm{Hb}$ for every preterm infant. Symptoms of anaemia (e.g., desaturations, bradycardias, increased oxygen requirement, and tachycardia) are non-specific and can be due to alternative causes including sepsis, evolving lung conditions (including worsening respiratory distress syndrome), or gastro-oesophageal reflux. Therefore, RBCT may not result in resolution of those clinical features [12].

Generally, RBCT are given to keep Hb levels above a certain threshold depending on the level of cardiorespiratory support required. Nearly half of RBCT given to ELBW infants are given during the first 2 weeks of life, when cardiorespiratory illness is most severe and laboratory blood tests are greatest; weekly phlebotomy losses during this period average $10-30 \%$ of the total blood volume $(10-25 \mathrm{~mL} / \mathrm{kg})$ [13].

RBCT are also given due to acute blood loss (e.g., fetalmaternal haemorrhage or placental abruption) or due to clinical symptoms regardless of the Hb level, or to an infant breathing on their own in air, but with an $\mathrm{Hb}$ below a certain threshold, with the intention of improving their weight gain [14].

However, no universally used $\mathrm{Hb}$ threshold for RBCT has been defined $[6,15]$, meaning that some infants are exposed to progressive anaemia which may result in gut hypoxia and injury [16].

\section{Current Guidelines}

The RBCT guidelines used in the Neonatal Unit $(\mathrm{NNU})$ are subjective and generalized $[17,18]$. Anaemia impacts the clinical status when the oxygen-carrying ca- pacity drops below an adequate threshold to meet the demands of oxygen consumption. Consequently, symptomatic anaemia does not occur consistently at predefined $\mathrm{Hb}$ levels but rather when there is an imbalance between oxygen delivery and consumption [11]. A universal $\mathrm{Hb}$ threshold for RBCT may not be appropriate for every preterm infant, as when this imbalance occurs will vary between individuals.

The decision for RBCT is made by clinicians based on their clinical judgement and national [19] or local guidelines. RBCT are administered when clinicians predict that the benefit will outweigh the risks. However, the reasons behind these judgements are not always evidence based and depend entirely on local guidance and the clinician's perception [20].

\section{Thresholds of Blood Transfusion}

There is no consensus regarding the thresholds at which preterm infants should receive a RBCT [21-24]. The $\mathrm{Hb}$ level is subjective and varies amongst different NNUs despite recent published national guidelines. The British Committee for Standards in Haematology (BCSH) published revised guidelines in $2016[19,25]$ and the second edition of the American practice guidelines for RBCT was published in 2007 [26]. These stressed the importance of defining poor cardiopulmonary status and its application in local practice. A comparison of guidelines from different countries (Table 1) highlights just how varied these thresholds are internationally, as well as within individual countries and within individual NNUs.

Various randomized controlled trials (RCT) used have different thresholds of transfusion to try and identify the optimal threshold for transfusion (Table 2). Despite multiple RCT, no significant differences have been found in short or long-term outcomes between the liberal and restrictive groups $[5,6,10,15,21-24]$. Furthermore, the thresholds used within each "restrictive" or "liberal" groups varied amongst the trials (Table 2), further demonstrating the lack of unity in transfusion policies.

A recent retrospective cohort study in Canada of preterm neonates born at $<30$ weeks of gestation found interesting temporal changes in their RBCT practice, with a trend towards fewer RBCT in those aged 26 weeks or older ( $p<0.01-0.04)$, but there was unchanged or increased use for those at 23-25 weeks of gestation. This may demonstrate a change in practice reflecting clinicians now having a higher threshold for transfusion for those slightly more mature preterm infants [3].
Howarth/Banerjee/Aladangady 
Table 1. Comparison of BCSH, American, Australian, and Canadian practice guidelines for RBC transfusion in newborn infants

\begin{tabular}{|c|c|c|c|c|}
\hline Clinical status & BCSH guideline & $\begin{array}{l}\text { American Red Cross } \\
\text { practice guideline }\end{array}$ & $\begin{array}{l}\text { Australian National Blood } \\
\text { Authority guideline }\end{array}$ & $\begin{array}{l}\text { Canadian Blood Services } \\
\text { guideline }\end{array}$ \\
\hline Anaemia in the first $24 \mathrm{~h}$ & $\begin{array}{l}\mathrm{Hb}<12 \mathrm{~g} / \mathrm{dL} \text { or } \\
\mathrm{Hct}<0.36\end{array}$ & - & $\begin{array}{l}\text { No respiratory support: } \\
\mathrm{Hb} 10-12 \mathrm{~g} / \mathrm{dL} \\
\text { Respiratory support } \\
\mathrm{Hb} 11-13 \mathrm{~g} / \mathrm{dL}\end{array}$ & $\begin{array}{l}\text { On ECMO and congenital } \\
\text { cyanotic heart disease } \\
\mathrm{Hb}<15 \mathrm{~g} / \mathrm{dL}\end{array}$ \\
\hline $\begin{array}{l}\text { Chronic oxygen dependency } \\
\text { Moderate cardiopulmonary } \\
\text { disease }\left(\mathrm{CPAP} \text { or } \mathrm{O}_{2}\right)\end{array}$ & $\mathrm{Hb}<11 \mathrm{~g} / \mathrm{dL}$ & Hct $30-35 \%$ & $\mathrm{Hb} 8.5-11 \mathrm{~g} / \mathrm{dL}$ & $\mathrm{Hb}<10 \mathrm{~g} / \mathrm{dL}$ \\
\hline
\end{tabular}

BCSH, British Committee for Standards in Haematology; Hb, haemoglobin; Hct, haematocrit; CPAP, continuous positive airway pressure.

Table 2. Hb threshold levels used by different randomized trials for RBC transfusions

\begin{tabular}{|c|c|c|}
\hline Trial & Restrictive threshold & Liberal threshold \\
\hline Blank et al. [5] & Transfusion according to clinical indication & Transfuse if $\mathrm{Hb}<100 \mathrm{~g} / \mathrm{L}$ \\
\hline Brooks et al. [10] & RBC transfusion when clinically symptomatic & $\mathrm{RBC}$ transfusion if $\mathrm{Hb}<133 \mathrm{~g} / \mathrm{L}$ \\
\hline Connelly et al. [22] & $\begin{array}{l}\text { 1st post-natal week: } 110 \mathrm{~g} / \mathrm{L} \\
\text { 2nd post-natal week: } \mathrm{FiO}_{2}>40 \%, 110 \mathrm{~g} / \mathrm{L} ; \mathrm{FiO}_{2}<40 \% \text {, } \\
90 \mathrm{~g} / \mathrm{L} \\
\text { 3rd post-natal week: } 80 \mathrm{~g} / \mathrm{L}^{\mathrm{a}}\end{array}$ & $\begin{array}{l}\text { 1st postnatal week: } 130 \mathrm{~g} / \mathrm{L} \\
\text { 2nd postnatal week: } \mathrm{FiO}_{2}>40 \%, 130 \mathrm{~g} / \mathrm{L} \text {; } \\
\mathrm{FiO}_{2}<40 \%, 100 \mathrm{~g} / \mathrm{L} \\
\text { 3rd postnatal week: } 80 \mathrm{~g} / \mathrm{dL} a\end{array}$ \\
\hline Mukhopadhyay et al. [23] & $\begin{array}{l}\text { Hb levels } \leq 100 \mathrm{~g} / \mathrm{L} \text { or } \\
\text { Hct } \leq 30 \%\end{array}$ & $\begin{array}{l}\text { Hb levels } \leq 133 \mathrm{~g} / \mathrm{L} \text { or } \\
\mathrm{Hct} \leq 40 \%\end{array}$ \\
\hline Bell et al. [15] & $\begin{array}{l}\text { Intubated: } 113 \mathrm{~g} / \mathrm{L} \\
\mathrm{O}_{2} \text { or CPAP: } 93 \mathrm{~g} / \mathrm{L} \\
\text { No respiratory support: } 67 \mathrm{~g} / \mathrm{L}\end{array}$ & $\begin{array}{l}\text { Intubated: } 153 \mathrm{~g} / \mathrm{L} \\
\mathrm{O}_{2} \text { or CPAP: } 127 \mathrm{~g} / \mathrm{L} \\
\text { No respiratory support: } 73 \mathrm{~g} / \mathrm{L}\end{array}$ \\
\hline Chen et al. [24] & $\begin{array}{l}\text { Intubated: } 116 \mathrm{~g} / \mathrm{L} \\
\text { CPAP: } 100 \mathrm{~g} / \mathrm{L} \\
\text { No respiratory support: } 73 \mathrm{~g} / \mathrm{L}\end{array}$ & $\begin{array}{l}\text { Intubated: } 150 \mathrm{~g} / \mathrm{L} \\
\text { CPAP: } 133 \mathrm{~g} / \mathrm{L} \\
\text { No respiratory support: } 100 \mathrm{~g} / \mathrm{L}\end{array}$ \\
\hline
\end{tabular}

CPAP, continuous positive airway pressure; Hb, haemoglobin; Hct, haematocrit; RBC, red blood cell. ${ }^{\text {a }}$ When capillary rather than central bloods were sampled the thresholds were $4 \%$ higher. 


\section{Physiological Adaptive Response to Anaemia and Blood Transfusion}

The general perception is that anaemia leads to tachycardia, hypotension, and poor perfusion and oxygen delivery to the tissues. Fredrickson et al. [27] examined the physiological adaptation to anaemia in preterm infants $(n=41)$ and found no significant change in oxygen consumption, mean $\mathrm{FiO}_{2}$, or mean $\mathrm{SaO}_{2}$ following RBCT.

Kasat et al. [14] used caregivers' perception of clinical improvement as a measure of benefit following RBCT; 18 patients were transfused based on guidelines, 36 based on caregivers' perception, and 24 based on both, and all 78 caregivers were surveyed. Pre-transfusion tachycardia was found to be the most sensitive predictor $(\mathrm{OR}=6.48 ; 95 \%$ CI 1.6-26; $p=0.005)$. RBCT significantly improved pretransfusion apnoea, bradycardia and desaturation $(p<$ $0.0029)$, tachycardia $(p<0.0276)$, and change in oxygen requirement $(p<0.0033)$ [14]. Similarly, Nelle et al. [28] $(n=33)$ also noticed a significant drop in heart rate (from 161 to 149 beats per min; $p=0.005)$ following RCBT [28]. Contrastingly Dani et al. [29] $(n=14)$ and Alkalay et al. [30] $(n=32)$ found no difference in heart rate following RBCT. However, it was subsequently demonstrated that heart rate correlates positively with the measured blood volume of preterm infants born at 24-32 weeks of gestation [31].

Systemic blood pressure is routinely monitored to determine the neonatal circulatory status and it has been shown to correlate with peripheral blood flow in hypotensive preterm infants [32]. Acute perinatal haemorrhage can lead to neonatal anaemia and hypotension requiring RBCT. The impact of RBCT on improving blood pressure is variable $[20,28,30]$ and measured blood volume does not correlate with mean arterial pressure in preterm infants [31].

\section{Blood Transfusion and Peripheral, Brain, and Gut Perfusion}

Near-infrared Spectroscopy (NIRS) provides a noninvasive, contemporaneous bedside measurement of regional tissue oxygen saturation $\left(\mathrm{rSO}_{2}\right)$ or the tissue oxygenation index reflecting perfusion and metabolism [33, 34]. To date most articles regarding the neonatal clinical application of NIRS have focused on cerebral measurements [35], but there is an increasing interest in measuring gut/splanchnic oxygenation. Several researchers have used NIRS to study the effect of RBCT on various tissues to identify a trigger for RBCT [36-38].
Fractional tissue oxygen extraction (FTOE) reflects the balance between oxygen delivery and consumption. In an observational study of 33 anaemic preterm infants van Hoften et al. [39] found that RBCT significantly improves cerebral tissue oxygenation $\left(\mathrm{CrSO}_{2}\right)$ and reduces FTOE. Similarly, Dani et al. [36] also noticed improvement in cerebral, renal, and splanchnic tissue oxygenation and a reduction in FTOE following RBCT in symptomatic anaemic preterm infants. Wardle et al. [32, 40, 41] reported that the peripheral FTOE was significantly higher in symptomatic anaemic preterm infants $(0.43 \pm$ $0.06)$ compared to asymptomatic $(0.33 \pm 0.05)$ and control $(0.35 \pm 0.06)$ infants, and the authors suggested that this may be used as a marker for the need for RBCT.

Bailey et al. [37] studied 30 anaemic preterm infants and demonstrated improvement in gut and cerebral oxygenation following RBCT. In a separate study, the same group showed that the splanchnic cerebral oxygenation ratio (SCOR) can be a useful marker for RBCT; infants with a low pre-transfusion SCOR $(\leq 0.73)$ were more likely to improve after RBCT (likelihood ratio $=2.8 ; 95 \% \mathrm{CI}$ 1.1-6.7) [42]. Seidel et al. [38] measured $\mathrm{crSO}_{2}$ and $\mathrm{prSO}_{2}$ before, during, immediately after, and $24 \mathrm{~h}$ after RBCT and noticed a significant improvement in cerebral and peripheral tissue oxygenation and perfusion (correlating with improvement in clinical symptoms of anaemia) upon transfusing those with $\mathrm{crSO}_{2}<55 \%$ compared to $\geq 55 \%$ [38]. Banerjee et al. [43, 44] reported that RBCT improves cerebral and gut tissue oxygenation in preterm infants of any post-natal age irrespectively of the feeding pattern, the pre-transfusion $\mathrm{Hb}$, or the presence or absence of PDA [43, 44].

These studies indicate that RBCT improves tissue oxygenation and that tissue oxygenation itself may play an important role in identifying the trigger for RBCT. Currently a study entitled "Effect of Blood Transfusion Practices on Cerebral and Somatic Oximetry," is ongoing; it is a secondary study within the Transfusion of Prematures (TOP) Trial [45]. They are using NIRS to examine the differences in cerebral oxygenation and FTOE between high- and low-Hb-threshold groups during RBCT to hopefully identify the optimal trigger for RBCT.

\section{Advantages of Blood Transfusion}

RBCT are life saving when they are given to replace acute blood lost by replenishing low circulating blood volumes. When given to anaemic preterm infants to replace the blood lost by phlebotomy, the benefits are not 
Table 3. Transfusion thresholds of haematocrit levels used in current trials

\begin{tabular}{|c|c|c|c|c|}
\hline \multirow[t]{2}{*}{ Age } & \multicolumn{2}{|c|}{ Liberal, \% } & \multicolumn{2}{|c|}{ Restrictive, \% } \\
\hline & critical & $\begin{array}{l}\text { non- } \\
\text { critical }\end{array}$ & critical & $\begin{array}{l}\text { non- } \\
\text { critical }\end{array}$ \\
\hline \multicolumn{5}{|c|}{ ETTNO Trial [52] } \\
\hline 3-7 days & $<41$ & $<35$ & $<34$ & $<28$ \\
\hline $8-21$ days & $<37$ & $<31$ & $<30$ & $<24$ \\
\hline$\geq 21$ days & $<34$ & $<28$ & $<27$ & $<21$ \\
\hline \multicolumn{5}{|l|}{ TOP Trial [45] } \\
\hline 1 week & 38 & 35 & 32 & 29 \\
\hline 2 weeks & 37 & 32 & 29 & 25 \\
\hline$\geq 3$ weeks & 32 & 29 & 25 & 21 \\
\hline
\end{tabular}

ETTNO, Effects of Transfusion Thresholds on Neurocognitive Outcome; TOP, Transfusion of Prematures.

clear. The proposed benefits of RBCT in this case derive from enhanced systemic oxygen transport.

Potential benefits of RBCT for anaemic preterm infants include prevention of apnoeas [46] and promotion of weight gain [47]. However, there were no significant benefits of RBCT in 2 large clinical trials, i.e., the Iowa Trial [15] and the PINT trial (Premature Infants in Need of Transfusion) [6], which compared liberal and restrictive RBCT criteria.

\section{Neurodevelopment and Blood Transfusion}

In the PINT Outcome study [48] in 451 enrolled infants, the primary outcome was available for 430 . The primary composite outcome was death or the presence of cerebral palsy, cognitive delay, or severe visual or hearing impairment. There was no statistically significant difference in the primary outcome, found in $94(45 \%)$ out of 208 subjects in the restrictive group and $82(38 \%)$ out of 213 subjects in the liberal group. A post hoc analysis with cognitive delay redefined (Mental Development Index score $<85$ ) showed that the Bayley Cognitive Mental Developmental Index scale was marginally better in infants who received a larger volume of RBCT.

In an observational follow-up study of premature infants receiving 2 different volumes of RBCT (15 vs. 20 $\mathrm{mL} / \mathrm{kg}$ ), the total transfused $\mathrm{RBC}$ volume per kilogram of bodyweight was not an independent predictor of the composite outcome ( $p=0.96, \mathrm{OR}=1.0 ; 95 \%$ CI $0.9-1.1)$ of post-discharge mortality, neuromotor developmental delay, blindness, or deafness, evaluated at a mean corrected age of 24 months [49].

Early RBCT suppress endogenous erythropoietin (EPO) production, lowering serum EPO levels at a critical time in neurodevelopment [50]. Nopoulos et al. [51] assessed brain structure and measured the brain volume in preterm infants, at an average age of 12 years, by using MRI scans of the brain of 44 infants from among the participants of the original Iowa blood transfusion study $(n=100)$ where preterm infants were randomized to either a liberal or a restrictive threshold for transfusion. Preterm infants who received RBCT using liberal guidelines were found to have a smaller brain volume.

There are 2 currently on-going RCT investigating the neurodevelopmental outcome at 24 months of age in relation to liberal and restrictive transfusion practices $[45,52]$ and each has different transfusion thresholds (Table 3). The thresholds were chosen by investigators by consensus opinion depending on the various transfusion practices of different institutions.

The Effects of Transfusion Thresholds on Neurocognitive Outcome of Extremely Low Birth-Weight Infants (ETTNO) study [52] is an observer-blinded RCT which started recruitment in August 2011 in Germany. 920 infants with a birth weight of 400-999 $\mathrm{g}$ will be randomized to restrictive or liberal transfusion trigger thresholds between 48 and $72 \mathrm{~h}$ of life, stratified by centre and birth weight. Their primary outcome measure will be the incidence of death or major neurodevelopmental impairment.

The Transfusion of Prematures (TOP) study [45] started in 2012 and infants with a birth weight $\leq 1,000 \mathrm{~g}$ and a gestational age $<29$ weeks are randomized to receive $\mathrm{RBCT}$ for either a high $\mathrm{Hb}$ (liberal transfusion) or a low $\mathrm{Hb}$ (restrictive transfusion), with the primary outcome being death or neurodisability in survivors at 22-26 months.

It is hoped that these trials will provide definitive data about the efficacy and safety of restrictive versus liberal RBCT guidelines in preterm infants and subsequently better answer the question of what is the optimal RBCT policy in terms of neurodevelopmental outcome.

\section{Disadvantages of Blood Transfusion}

\section{General Disadvantages}

The risks associated with cross-matching are significantly lower due to rigorous screening and vigilance [53]. 
There are the complications of "oxidative diseases" which include elevated plasma non-transferrin-bound iron [54] and RBCT leading to possible overloading of the liver with iron [55] in very low birth weight (VLBW) infants, the clinical implications of which is unknown. Some studies have shown a relationship between RBCT and risk of IVH [8], BPD [54, 56, 57], and ROP [58]. RBCT has also been reported as an independent risk factor of intrahospital mortality [59]. However, these might be confounded by a low birth weight, gestational age, a longer duration of oxygen therapy, and a state of tissue hypoxia in anaemic infants.

In the immediate post-natal period the need for RBCT is higher, especially in extremely preterm infants in whom the benefits outweigh risks. However, there is also a cohort of infants not transfused in the first few weeks of life as they are haemodynamically stable who then receive a later "top up" RBCT. The normal physiological post-natal adaption results in a $\mathrm{Hb}$ nadir and should we be transfusing these infants or rather waiting for their own endogenous erythropoiesis? Keir et al. [60] found that RBCT at 21 days or more of life in previously transfusion-naive preterm infants was associated with increased odds of Chronic Lung Disease (CLD) (AOR $=1.78$; 95\% CI 1.432.22) but not associated with severe ROP or mortality. However, the authors found a statistically significant longer duration of mechanical ventilation in this group, which would clearly contribute to the increased odds of CLD.

\section{Anaemia, Blood Transfusion, and NEC}

Perhaps the greatest controversy surrounding RBCT in preterm infants is its relationship with NEC. There have been reports of a temporal association between RBCT and NEC occurring within $72 \mathrm{~h}$ of this transfusion. $25-35 \%$ of NEC cases are temporally associated with RBCT and the terms "transfusion-related NEC" or "transfusion-related acute gut injury" have been coined [6163]. The available evidence for this in published studies is contentious and inconclusive. There is no clear causal link and the underlying mechanism between any associations is unknown $[7,20,24,37,61,64-69]$.

The increase in superior mesenteric artery blood flow in response to feeding in anaemic preterm infants is well known [68] and, as disturbances in blood flow and organ perfusion are an important aetiology in the development of NEC, changes in this response to feeding during blood transfusion have been studied. In a clinical trial of 22 in- fants (gestational age, $27.3 \pm 2.3$ weeks; corrected gestational age, $31.8 \pm 2.9$ weeks; chronological age of transfusion, 3-71 days; and mean, 31.2 days) where infants were randomized to fed and not-fed groups during a blood transfusion, Krimmel et al. [69] demonstrated that this increased flow in the superior mesenteric artery following feeding, which was evident pre-transfusion, was lacking in the immediate post-transfusion state. They concluded that this lack of a response may contribute to transfusionassociated NEC in these infants.

Perciaccante [70] suggested that feeding during RBCT increases the incidence of NEC. In the first phase of the study, 7 out of 18 (38.9\%) infants developed NEC within $48 \mathrm{~h}$ of RBCT. In the second phase, by withholding feeds, none of the infants developed NEC within $48 \mathrm{~h}$ of RBCT. In a case-control study El-Dib et al. [71] compared the incidence of NEC 18 months before and after implementation of a strict policy of withholding feeds during RBCT. They reported a significant decrease in NEC from 5.3 to $1.3 \%$ ( $p=0.047$ ) following implementation of the new policy. Some NNUs use this as a basis to withhold feeds whilst administering RBCT to a preterm infant. In a case-control study (111 preterm infants with NEC stage 2a or higher were compared with 222 matched controls) there was an increased odds of developing NEC within $24 \mathrm{~h}(\mathrm{OR}=7.60, p=0.001)$ and $48 \mathrm{~h}(\mathrm{OR}=5.55, p=$ $0.001)$ after RBCT [72]. In a large retrospective cohort study of 2,311 infants, Paul et al. [73] demonstrated that infants who received RBCT had increased adjusted odds $(\mathrm{OR}=2.3 ; 95 \%$ CI 1.2-4.2) of developing NEC. Recently retrospective data of 115 infants with NEC demonstrated that RBCT $<72 \mathrm{~h}$ before NEC onset was associated with a surgical intervention (pairwise adjusted $p<0.001$ ), but multivariate logistic regression analysis "revealed RBCT is not an independent risk factor for surgical NEC" [74].

The confusion amongst these studies is re-iterated in 2 meta-analyses. One of observational data concluded that recent exposure to RBCT was associated with developing NEC [20], but another involving only RCT reported no difference in the incidence of NEC between infants receiving conservative treatment compared to those receiving liberal RBCT (pooled OR $=1.67 ; 95 \%$ randomeffects CI 0.82-3.38) [32]. A very recently published article examining the quality of evidence behind transfusion-related NEC found the overall quality to be "very low" and "not sufficient to support a practice recommendation around RBCT in the context of preventing the development of NEC" [75].

Due to the substantial variation in clinical practice in terms of $\mathrm{Hb}$ thresholds for RBCT, some preterm infants
Howarth/Banerjee/Aladangady 
are exposed to chronic anaemia. It has been proposed that anaemia causes reduced mesenteric blood flow leading to intestinal hypoxia and subsequent mucosal injury $[8,36-$ 39]. There is evidence to suggest that this transient hypoxia followed by re-oxygenation (e.g., after RBCT to treat anaemia) is a component of the pathogenesis of diseases involving a change in blood flow to the bowel, including NEC, through reperfusion injury $[11,18,22-24$, 40]. The association between $\mathrm{Hb}$, tissue perfusion, and oxygen delivery is not clear [39]; the critical $\mathrm{Hb}$ level at which the risk from anaemia outweighs the risk of NEC from RBCT has not been identified [64, 71].

Other authors suggest that RBCT induce a pro-inflammatory response which may underpin the pathogenesis of transfusion-related NEC. Dani et al. [76] prospectively examined 20 infants with a gestational age $<32$ weeks and measured serum levels of various cytokines before and at various time points after RBCT up to $48 \mathrm{~h}$ post-RBCT. That small study showed a significant increase in IL- $1 \beta$, IL- 8 , IFN- $\gamma$, IL-17, MCP-1, IP-10, and ICAM-1 after RBCT. However, they found unchanged values of IL- 6 and TNF- $\alpha$, known to be players in the development of NEC, but the authors give several justifiable reasons for this in their discussion, centred around study design.

Patel et al. [16] looked at 598 VLBW infants and found that severe anaemia in a given week (defined as $\mathrm{Hb}<8 \mathrm{~g}$ / $\mathrm{dL}$ ), was associated with a significantly increased risk of NEC (adjusted cause-specific HR 5.99; 95\% CI 2.00$18.00 ; p=0.01$ ) but not RBCT in a given week (adjusted cause-specific HR 0.44; 95\% CI 0.17-1.12; $p=0.09$ ). This is an important study as it involved large numbers, both of total recruited infants, and because 4,565 longitudinal measurements of $\mathrm{Hb}$ were evaluated.

In support of this, EPO has been shown to be protective against NEC [42-44] and one of the hypotheses for this protective effect is secondary to prevention of anaemia of prematurity. Recent Cochrane analyses of early [77] and late [52] rEPO usage concluded that there was a reduction in the number and volume of RBCT but the clinical significance was questioned. Other hypotheses include: (1) protection against ischaemia/reperfusion injury in adult rats [78], (2) preservation of the intestinal barrier function in a rat NEC model [79], (3) inhibition of nitric oxide production [80], and (4) reduction of inflammatory mediators and apoptosis [81]. A recent human study in China [82] showed that in 94 infants with NEC, those treated with $\mathrm{rEPO}(n=52)$ compared to controls $(n=42)$ had significantly lower levels of TNF- $\alpha$ and IL-6 and a significantly lower death and complication rate $(p<0.05)$. Ledbetter and Juul [83] also showed a decreased incidence of NEC in preterm infants given EPO compared to controls.

\section{RBCT and ROP and IVH}

The PINT Study [6] found no statistically significant differences between liberal and restrictive transfusion groups in all of their secondary outcomes including severe ROP and brain injury on cranial ultrasound.

However, a recent cohort study of 120 ELBW infants found that the number of RBCT within 30 days was correlated with the risk of developing $\mathrm{ROP}(\mathrm{OR}=1.27 ; 95 \%$ CI 1.04-1.55; $p=0.02$ ) [84]. This is in agreement with Dani et al. [85], who showed that RBCT volume was associated with $\mathrm{ROP}(\mathrm{OR}=1.16$ for the first week of life and 2.92 for the first 60 days of life) in infants with a birth weight of $<1,250 \mathrm{~g}$. However, in agreement with Kirpalani et al. [6], Brooks et al. [86] found no significant differences in ROP incidence between restrictive and liberal RBCT. Valieva et al. [20] also found no association between ROP and RBCT in 60 ELBW infants.

Wang et al. [84] report that the number of RBCT within 7 days of life was associated with severe IVH (OR = 1.53 ; 95\% CI 1.09-2.16, $p=0.014$ ), although they admit they could not decipher whether RBCT was the cause or result. Baer et al. [87] retrospectively looked at VLBW infants who initially had no IVH on CrUSS and later had a severe haemorrhage $(n=54)$ matched with controls who did not develop IVH (1:2). They reported that cases were more likely to have had a RBCT $(p<0.001)$ and RBCT given before IVH development are an independent risk factor for developing a severe IVH. Christensen et al. [88] found that after implementing a more restrictive RBCT policy they decreased the incidence of severe IVH.

\section{Conclusions}

There is no debate that RBCT is life saving in an acutely bleeding preterm infant. Nevertheless, the optimal timing and triggers of "top-up" RBCT remain elusive despite several randomized trials. Even with the vast amount of studies examining RBCT it remains unclear whether a liberal or restrictive transfusion policy is best, particularly with regards to the neonatal morbidities of NEC, ROP, and IVH, as well as long-term neurodevelopmental outcomes. It is hoped that the ETTNO [52] and TOP [45] studies will enlighten us to some degree. 
However, very little is known about the adaptive responses to anaemia in VLBW infants and the effects of RBCT at various levels of anaemia. None of the studies stratified the patients according to gestational and chronological age and it is likely that neonatal haemodynamics are variable in these groups. There is therefore a critical need for future research to involve a detailed examination of both the adaptive physiological response and tissue injury due to anaemia of varying degrees and the acute physiological responses to RBCT at various levels of anaemia in different gestational and post-natal ages of preterm infants, as well as examining the influence of placental transfusion practices on these physiological responses. It is only with this currently lacking vital information that we will finally be able to answer the question of how should we as clinicians optimize our RBCT policies for preterm infants? Until then it is our recommendation that clinicians use national guidelines or at least within individual units all adhere to the same policy to reduce the current level of variation in RBCT practice.

\section{Ethics Statement}

Not applicable as this is a review article.

\section{Disclosure Statement}

The authors declare no conflict of interests.

\section{Funding Sources}

Dr. Claire Howarth was funded by the Barts Charity Research Grant Award (MGU0388), and the authors are grateful to Barts Charity for their funding support.

\section{References}

1 Costeloe KL, Hennessy EM, Haider S, Stacey F, Marlow N, Draper ES: Short term outcomes after extreme preterm birth in England: comparison of two birth cohorts in 1995 and 2006 (the EPICure studies). BMJ 2012; 345:e7976.

2 Aladangady N, Asamoah F, Banerjee J: Blood transfusion and short term outcomes in premature infants. E-PAS 2014, p 4113252.

3 Keir AK, Yang J, Harrison A, Pelausa E, Shah PS: Temporal changes in blood product usage in preterm neonates born at less than 30 weeks' gestation in Canada. Transfusion 2015;55:1340-1346.

-4 Maier RF, Sonntag J, Walka MM, Liu G, Metze BC, Obladen M: Changing practices of red blood cell transfusions in infants with birth weights less than $1,000 \mathrm{~g}$. J Pediatr 2000;136: 220-224.

5 Blank JP, Sheagren TG, Vajaria J, Mangurten $\mathrm{HH}$, Benawra RS, Puppala BL: The role of $\mathrm{RBC}$ transfusion in the premature infant. Am J Dis Child 1984;138:831-833.

-6 Kirpalani H, Whyte RK, Andersen C, Asztalos EV, Heddle N, Blajchman MA, Peliowski A, Rios A, LaCorte M, Connelly R, Barrington K, Roberts RS: The Premature Infants in Need of Transfusion (PINT) study: a randomized, controlled trial of a restrictive (low) versus liberal (high) transfusion threshold for extremely low birth weight infants. J Pediatr 2006;149:301-307.

7 Mohamed A, Shah PS: Transfusion associated necrotizing enterocolitis: a meta-analysis of observational data. Pediatrics 2012;129:529_ 540 .
8 Baer VL, et al: Red blood cell transfusion of preterm neonates with a Grade 1 intraventricular hemorrhage is associated with extension to a grade 3 or 4 hemorrhage. Transfusion 2011;51:1933-1939.

9 Zhang Z, Huang X, Lu H: Association between red blood cell transfusion and bronchopulmonary dysplasia in preterm infants. Sci Rep 2014;4:4340.

10 Brooks SE, Marcus DM, Gillis D, Pirie E, Johnson MH, Bhatia J: The effect of blood transfusion protocol on retinopathy of prematurity: a prospective, randomized study. Pediatrics 1999;104:514-518.

11 Alverson DC: The physiologic impact of anemia in the neonate. Clin Perinatol 1995;22: 609-625.

12 Banerjee J, Asamoah FK, Singhvi D, Kwan AWG, Morris JK, Aladangady N: Haemoglobin level at birth is associated with short term outcomes and mortality in preterm infants. BMC Med 2015;13.

$\checkmark 13$ Widness JA, Madan A, Grindeanu LA, Zimmerman MB, Wong DK, Stevenson DK: Reduction in red blood cell transfusions among preterm infants: results of a randomized trial with an in-line blood gas and chemistry monitor. Pediatrics 2005;115:1299-1306.

14 Kasat K, Hendricks-Munoz KD, Mally PV: Neonatal red blood cell transfusions: searching for better guidelines. Blood Transfus 2011;9:86-94.

15 Bell EF, Strauss RG, Widness JA, Mahoney LT, Mock DM, Seward VJ, Cress GA, Johnson KJ, Kromer IJ, Zimmerman MB: Randomized trial of liberal versus restrictive guidelines for red blood cell transfusion in preterm infants. Pediatrics 2005;115:1685-1691.
16 Patel RM, Knezevic A, Shenvi N, Hinkes M, Keene S, Roback JD, Easley KA, Josephson CD: Association of red blood cell transfusion, anemia, and necrotizing enterocolitis in very low-birth-weight infants. JAMA 2016;315: 889-897.

17 Luban NL: Neonatal red blood cell transfusions. Curr Opin Hematol 2002;9:533-536.

18 Luban NL: Neonatal red blood cell transfusions. Vox Sang 2004;87(suppl 2):184-188.

19 Gibson BE, Todd A, Roberts I, Pamphilon D, Rodeck C, Bolton-Maggs P, Burbin G, Duguid J, Boulton F, Cohen H, Smith N, McClelland DB, Rowley M, Turner G: Transfusion guidelines for neonates and older children. $\mathrm{Br}$ J Haematol 2004;124:433-453.

20 Valieva OA, Strandjord TP, Mayock DE, Juul SE: Effects of transfusions in extremely low birth weight infants: a retrospective study. J Pediatr 2009;155:331-337.e331.

21 Ransome OJ, Moosa EA, Mothebe FM, et al: Are regular "top-up" transfusions necessary in otherwise well, growing premature infants? S Afr Med J 1989;75:165-166.

22 Connely RJ, Whyte RK: Early versus late red cell transfusion in low birth weight infants (abstract). Pediatr Res 1998;43:170.

23 Mukhopadhyay K, Ghosh PS, Narang A, Dogra MR: Cut off level for RBC transfusion in sick preterm neonates. Pediatr Res 2004;55: 288A.

24 Chen HL, Tseng HI, Lu CC, Yang SN, Fan HC, Yang RC: Effect of blood transfusions on the outcome of very low body weight preterm infants under two different transfusion criteria. Pediatr Neonatol 2009;50:110-116. 
25 British Committee for Standards in Haematology: British Committee for Standards in Haematology Clinical Guideline: Transfusion for Fetuses, Neonates and Older Children. London, BCSH, 2016.

26 Miller Y, Bachowski G, Benjamin R: Practice Guidelines for Blood Transfusion, ed 2. Washington, American Red Cross, 2007, pp 5-17.

-27 Fredrickson LK, Bell EF, Cress GA, Johnson KJ, Zimmerman MB, Mahoney LT, Widness JA, Strauss RG: Acute physiological effects of packed red blood cell transfusion in preterm infants with different degrees of anaemia. Arch Dis Child Fetal Neonatal Ed 2010; 96:F249-F253.

28 Nelle M, Hocker C, Zilow EP, Linderkamp O: Effects of red cell transfusion on cardiac output and blood flow velocities in cerebral and gastrointestinal arteries in premature infants. Arch Dis Child Fetal Neonatal Ed 1994; 71:F45-F48.

29 Dani C, Pezzati M, Martelli E, Prussi C, Bertini G, Rubaltelli FF: Effect of blood transfusions on cerebral haemodynamics in preterm infants. Acta Paediatr 2002;91:938-941.

- 30 Alkalay AL, Galvis S, Ferry DA, Simmons CF, Krueger RC Jr: Hemodynamic changes in anemic premature infants: are we allowing the hematocrits to fall too low? Pediatrics 2003;112:838-845.

- 31 Aladangady N, Aitchison TC, Beckett C, Holland BM, Kyle BM, Wardrop CA: Is it possible to predict the blood volume of a sick preterm infant? Arch Dis Child Fetal Neonatal Ed 2004;89:F344-F347.

32 Wardle SP, Yoxall CW, Weindling AM: Peripheral oxygenation in hypotensive preterm babies. Pediatr Res 1999;45:343-349.

33 Murkin JM, Arango M: Near-infrared spectroscopy as an index of brain and tissue oxygenation. Br J Anaesth 2009;103(suppl 1):i3i13.

34 Banerjee J, Aladangady N: Biomarkers to decide red blood cell transfusion in newborn infants. Transfusion 2014;54:2574-2582.

- 35 Leung TS, Aladangady N, Elwell CE, Delpy DT, Costeloe K: A new method for the measurement of cerebral blood volume and total circulating blood volume using near infrared spatially resolved spectroscopy and indocyanine green: application and validation in neonates. Pediatr Res 2004;55:134-141.

-36 Dani C, Pratesi S, Fontanelli G, Barp J, Bertini G: Blood transfusions increase cerebral, splanchnic, and renal oxygenation in anemic preterm infants. Transfusion 2010;50:12201226.

-37 Bailey SM, Hendricks-Munoz KD, Wells JT, Mally P: Packed red blood cell transfusion increases regional cerebral and splanchnic tissue oxygen saturation in anemic symptomatic preterm infants. Am J Perinatol 2010;27: 445-453.
38 Seidel D, Blaser A, Gebauer C: Changes in regional tissue oxygenation saturation and desaturations after red blood cell transfusion in preterm infants. J Perinatol 2013;33:282-287.

39 van Hoften JC, Verhagen EA, Keating P, ter Horst HJ, Bos AF: Cerebral tissue oxygen saturation and extraction in preterm infants before and after blood transfusion. Arch Dis Child Fetal Neonatal Ed 2010;95:F352-F358.

40 Wardle SP, Weindling AM: Peripheral fractional oxygen extraction and other measures of tissue oxygenation to guide blood transfusions in preterm infants. Semin Perinatol 2001;25:60-64.

41 Wardle SP, Garr R, Yoxall CW, Weindling AM: A pilot randomised controlled trial of peripheral fractional oxygen extraction to guide blood transfusions in preterm infants. Arch Dis Child Fetal Neonatal Ed 2002; 86:F22-F27.

42 Bailey SM, Hendricks-Muñoz KD, Mally P: Splanchnic-cerebral oxygenation ratio as a marker of preterm infant blood transfusion needs. Transfusion 2012;52:252-260.

43 Banerjee J, Leung TS, Aladangady N: Blood transfusion in preterm infants improves intestinal tissue oxygenation without alteration in blood flow. Vox Sang 2016;1111:399-408.

44 Banerjee J, Leung TS, Aladangady N: Effect of blood transfusion on intestinal blood flow and oxygenation in extremely preterm infants during first week of life. Transfusion 2016;56: 808-815.

45 Kirpalani H, Bell E, D’Angio C, Hintz S, Kennedy K, Ohls R, Poindexter B, Schibler K, Schmidt B, Vohr B, Widness J, Das A, Higgins R, Zupancic J, Roberts R, Whyte R, Chaudhary A, Johnson K: Protocol: Transfusion of Prematures (TOP) trial - does a liberal red blood cell transfusion strategy improve neurologicallyintact survival of extremely-low-birth-weight infants as compared to a restrictive strategy? ClinicalTrials.gov 2012;NCT01702805.

46 Ross MP, Christensen RD, Rothstein G, Koenig JM, Simmons MA, Noble NA, Kimura RE: A randomized trial to develop criteria for administering erythrocyte transfusions to anemic preterm infants 1 to 3 months of age. J Perinatol 1989;9:246-253.

47 Meyer J, Sive A, Jacobs P: Empiric red cell transfusion in asymptomatic preterm infants. Acta Paediatr 1993;82:30-34.

48 Whyte RK, Kirpalani H, Asztalos EV, Andersen C, Blajchman M, Heddle N, LaCorte M, Robertson CM, Clarke MC, Vincer MJ, Doyle LW, Roberts RS: Neurodevelopmental outcome of extremely low birth weight infants randomly assigned to restrictive or liberal hemoglobin thresholds for blood transfusion. Pediatrics 2009;123:207-213.

49 von Lindern JS, Khodabux CM, Hack KE, van Haastert IC, Koopman-Esseboom C, van Zwieten PH, Brand A, Walther FJ: Long-term outcome in relationship to neonatal transfusion volume in extremely premature infants: a comparative cohort study. BMC Pediatr 2011;11:48-53.
50 Ohls RK, Ehrenkranz RA, Das A, Dusick AM, Yolton K, Romano E, Delaney-Black V, Papile LA, Simon NP, Steichen JJ, Lee KG: Neurodevelopmental outcome and growth at 18 to 22 months' corrected age in extremely low birth weight infants treated with early erythropoietin and iron. Pediatrics 2004;114:1287-1291.

51 Nopoulos PC, Conrad AL, Bell EF, Strauss RG, Widness JA, Magnotta VA, Zimmerman $\mathrm{MB}$, Georgieff MK, Lindgren SD, Richman LC: Long-term outcome of brain structure in premature infants: effects of liberal vs. restricted red blood cell transfusions. Arch Pediatr Adolesc Med 2011;165:443-450.

52 Aher S, Ohlsson A: Late erythropoietin for preventing red blood cell transfusion in preterm and/or low birth weight infants. Cochrane Database Syst Rev 2006;3:CD004868.

53 Stainsby D, Jones H, Wells AW, Gibson B, Cohen H: Adverse outcomes of blood transfusion in children: analysis of UK reports to the serious hazards of transfusion scheme 1996-2005. Br J Haematol 2008;141:73-79.

- 54 Hirano K, Morinobu T, Kim H, Hiroi M, Ban $\mathrm{R}$, Ogawa S, Ogihara $\mathrm{H}$, Tamai $\mathrm{H}$, Ogihara $\mathrm{T}$ : Blood transfusion increases radical promoting non-transferrin bound iron in preterm infants. Arch Dis Child Fetal Neonatal Ed 2001; 84:F188-F193.

$55 \mathrm{Ng}$ PC, Lam CW, Lee CH, To KF, Fok TF, Chan $\mathrm{IH}$, Wong E: Hepatic iron storage in very low birthweight infants after multiple blood transfusions. Arch Dis Child Fetal Neonatal Ed 2001;84:F101-F105.

56 Collard KJ: Is there a causal relationship between the receipt of blood transfusions and the development of chronic lung disease of prematurity? Med Hypotheses 2006;66:355364.

57 Cooke RW, Drury JA, Yoxall CW, James C: Blood transfusion and chronic lung disease in preterm infants. Eur J Pediatr 1997;156:4750.

58 Hesse L, Eberl W, Schlaud M, Poets CF: Blood transfusion: iron load and retinopathy of prematurity. Eur J Pediatr 1997;156:465-470.

-59 dos Santos AM, Guinsburg R, de Almeida MF, Procianoy RS, Leone CR, Marba ST, Rugolo LM, Fiori HH, Lopes JM, Martinez FE: Red blood cell transfusions are independently associated with intra-hospital mortality in very low birth weight preterm infants. J Pediatr 2011;159:371-376.e371-e373.

60 Keir A, Aziz K, McMillan D, Monterrosa L, Ojah C, Lee S, Shah PS: Red blood cell transfusions at 21 days of age or older in previously transfusion-naive very preterm infants: association with neonatal outcomes. Am J Perinatol 2015;32:1139-1144.

61 Mally P, Golombek SG, Mishra R, Nigam S, Mohandas K, Depalhma H, LaGamma EF: Association of necrotizing enterocolitis with elective packed red blood cell transfusions in stable, growing, premature neonates. Am J Perinatol 2006;23:451-458. 
62 Marin T, Moore J, Kosmetatos N, Roback J, Weiss P, Higgins M, McCauley L, Strickland O, Josephson C: Red blood cell transfusionrelated necrotising enterocolitis in very low birthweight infants: a near infrared spectroscopy investigation. Transfusion 2013;53: 2650-2658.

63 Josephson CD, Wesolowski A, Bao G, SolaVisner MC, Dudell G, Castillejo MI, Shaz BH, Easley KA, Hillyer CD, Maheshwari A: Do red cell transfusions increase the risk of necrotizing enterocolitis in premature infants? J Pediatr 2010;157:972-978.

- 64 Blau J, Calo JM, Dozor D, Sutton M, Alpan G, La Gamma EF: Transfusion-related acute gut injury: necrotizing enterocolitis in very low birth weight neonates after packed red blood cell transfusion. J Pediatr 2011;158:403-409.

- 65 Christensen RD: Association between red blood cell transfusions and necrotizing enterocolitis. J Pediatr 2011;158:349-350.

- 66 Christensen RD, Lambert DK, Henry E, Wiedmeier SE, Snow GL, Baer VL, Gerday E, Ilstrup S, Pysher TJ: Is "transfusion-associated necrotizing enterocolitis" an authentic pathogenic entity? Transfusion 2010;50: 1106-1112.

-67 Stritzke AI, Smyth J, Synnes A, Lee SK, Shah PS: Transfusion-associated necrotising enterocolitis in neonates. Arch Dis Child Fetal Neonatal Ed 2013;98:F10-F14.

68 Leidig E: Doppler analysis of superior mesenteric artery blood flow in preterm infants. Arch Dis Child 1989;64:476-480.

69 Krimmel GA, Baker R, Yanowitz TD: Blood transfusion alters the superior mesenteric artery blood flow velocity response to feeding in premature infants. Am J Perinatol 2009;26: 99-105.

70 Perciaccante JV: Necrotizing enterocolitis associated with packed red blood cell transfusions in premature neonates. E-PAS 2008, p 58298.

-71 El-Dib M, Narang S, Lee E, Massaro AN, Aly $\mathrm{H}$ : Red blood cell transfusion, feeding and necrotizing enterocolitis in preterm infants. J Perinatol 2011;31:183-187.
2 Singh R, Visintainer PF, Frantz ID 3rd, Shah BL, Meyer KM, Favila SA, Thomas MS, Kent DM: Association of necrotizing enterocolitis with anemia and packed red blood cell transfusions in preterm infants. J Perinatol 2011; 31:176-182.

73 Paul DA, Mackley A, Novitsky A, Zhao Y, Brooks A, Locke RG: Increased odds of necrotizing enterocolitis after transfusion of red blood cells in premature infants. Pediatrics 2011;127:635-641.

74 Cunningham KE, Okolo FC, Baker R, Mollen KP, Good M: Red blood cell transfusion in premature infants leads to worse necrotising enterocolitis outcomes. J Surg Res 2017;213: 158-165.

75 Hay S, Zupancic J, Flannery D, Dukhovny D: Should we believe in transfusion-associated enterocolitis? Applying a GRADE to the literature. Semin Perinatol 2017;41:80-91.

76 Dani C, Poggi C, Gozzini E, Leonardi V, Sereni A, Abbate R, Gori AM: Red blood cell transfusions can induce proinflammatory cytokines in preterm infants. Transfusion 2017; 57:1304-1310.

77 Ohlsson A, Aher SM: Early erythropoietin for preventing red blood cell transfusion in preterm and/or low birth weight infants. Cochrane Database Syst Rev 2012;9:CD004863.

78 Guneli E, Cavdar Z, Islekel H, Sarioglu S, Erbayraktar S, Kiray M, Sokmen S, Yilmaz O, Gokmen N: Erythropoietin protects the intestine against ischemia/reperfusion injury in rats. Mol Med 2007;13:509-517.

79 Shiou SR, Yu Y, Chen S, Ciancio MJ, Petrof EO, Sun J, Claud EC: Erythropoietin protects intestinal epithelial barrier function and lowers the incidence of experimental necrotizing enterocoloitis. J Biol Chem 2011;8:1212312132.
80 Kumral A, Baskin H, Duman N, Yilmaz O, Tatli M, Ozer E, Gokmen N, Genc S, Ozkan $\mathrm{H}$ : Erythropoietin protects against necrotizing enterocolitis of newborn rats by the inhibiting nitric oxide formation. Biol Neonate 2003;84:325-329.

81 Juul SE, Joyce AE, Zhao Y, Ledbetter DJ: Why is erythropoietin present in human milk? Studies of erythropoietin receptors on enterocytes of human and rat neonates. Pediatr Res 1999;46:263-268.

82 Qi W, Shen Q, Zhang L, Han LP, Wang S: Study on the inflammatory intervention of erythropoietin on NEC. Exp Ther Med 2016; 11:2221-2224.

83 Ledbetter DJ, Juul SE: Erythropoietin and the incidence of necrotizing enterocolitis in infants with very low birth weight. J Pediatr Surg 2000;35:178-182.

84 Wang YC, Chan OW, Chiang MC, Yang PH, Chu SM, Hsu JF, Fu RH, Lien R: Red blood cell transfusion and clinical outcomes in extremely low birth weight preterm infants. Pediatr Neonatol 2017;58:216-222.

85 Dani C, Reali MF, Bertini G, E. M, Pezzati M, Rubaltelli FF: The role of blood transfusions and iron uptake on retinopathy of prematurity. Early Hum Dev 2001;62:57-63.

- 86 Brooks SE, Marcus DM, Gillis D, Pirie E, Johnson MH, Bhatia J: The effect of blood transfusion protocol on retinopathy of prematurity: a prospective, randomized study. Pediatrics 1999;104:514-518.

87 Baer VL, Lambert DK, Henry E, Snow GL, Butler A, Christensen RD: Among very low birth weight neonates is red blood cell transfusion an independent risk factor for subequently developing a severe intraventricular hemorrhage? Transfusion 2011;51:11701178.

88 Christensen RD, Baer VL, Lambert DK, Ilstrup SJ, Eggert LD, Henry E: Association among very low birthweight neonates between red blood cell transfusions in the week after birth and severe intraventricular hemorrhage. Transfusion 2014;54:104-108. 